\title{
The Effect of Extraversion Personality, Emotional Intelligence and Job Satisfaction to Teachers' Work Spirit Islmaic Junior High School (MTs) Deli Serdang North Sumatra
}

\author{
Candra Wijaya,Syarbaini Saleh \\ The State Islamic University of North Sumatera
}

\begin{abstract}
The Aims of the research were to explore the effects of extraversion personality, emosional intelligence, and job satisfaction to teachers work spirit at Islamic Junior Hight schools at Deli serdang North Sumatera. This research used quantitaive approach and used path analysis to know the effect of the variavbles. The data were taken from 136 teachers and using a set of questionaries Likert Scale Model. The results of the research revealed that all variables observed have significant effect to teachers work spirit.
\end{abstract}

Keywords: effect, extraversion personality, emosional intelligence, job satisfaction, teachers work spirit, Islamic Junior Hight schools

\section{BACKGROUND}

Education is a strategic effort to improve the knowledge, skills and mental attitude of human resources. Through education, is expected to create quality human resources for national development. Education is also one key to raise the dignity of a nation.Various attempts have been made to improve the quality of national education, for example, national and local curriculum development, improving the competence of teachers through training, teacher certification, procurement of books and teaching tools, provision and improvement of educational facilities, as well as improving the quality of school management.

But it seems all these efforts have not shown encouraging results. The phenomenon shows that the quality of education is still low. The low quality of education is based on reports from the United National Development Project (UNDP) in 2008 stated that the quality of Indonesian human resources was ranked 109, far below the Brunei which was ranked 27th, Singapore 28th, Malaysia 63rd, Thailand to -81, and Sri Lanka to 104. These data indicate that the quality of education in Indonesia is still low (http: hdr.Undp.org/en/statistics).

Purba (2009: 91) stated that one of the problems facing the education of our nation is the issue of quality of education at all levels and educational unit. It is also supported by the National Examination SMP / MTs in 2010 by Waspada Newspaper online, as many as 6858 students of SMP / MTs in North Sumatra province declared not pass and must comply with the re-examination. While the number of students who passed reached 97.17 percent of the 242,587 students who take the National Examination(http://rumahnajwa.wordpress.com/2010/05/06/).

Therefore, the quality of education needs to be improved by increasing the ability of teachers in performing their duties as an educator in the formation of personality as well as providing knowledge and skills. The teacher's task will not run properly without considering the factors that influence the success of teachers in performing their duties.Many factors can increase the success of teachers in teaching, both factors of the teachers themselves or from outside himself such as, the work spirit of teachers, extroversion personality and emotional intelligence. Factors affecting job satisfaction is work spirit of teachers in the implementation of their duties in teaching or educating students.

By paying attention to a few things that have been put forward in the background of the problems, it can be identified as problems associated with teachers' work spirit. These problems can be identified as follows: (1) Is the extrovert personality affect the teachers' work spirit?, (2) Is the emotional intelligence affect the teachers' work spirit?, and (3) Is the level of satisfaction of teachers affect the teachers' work spirit?

\section{THEORETICAL FRAMEWORK:}

In this study, researchers discussed some theories about:teachers' work spirit, extraversion personality, emotional intelligence and job satisfaction of teachers.

\section{Work Spirit}

According to Straus dan Sayless (1999),Hasibuan (2007: 105) work spirit is the desire and determination one has done a good job and disciplined to achieve maximum performance. Meanwhile, according to Alex S 
Nitisemito (2004: 160) work spirit is the ability to do the job even harder, so that the work would be expected to be faster and better. Then Davis (2000) states that work spirit is the willingness of their feelings and behaviors that increase a person's work to generate more and better employment. Work spirit is a positive working atmosphere contained within an organization and revealed in the attitude of individuals and groups that support all aspects of the work including the environment, cooperation with others that optimally match the interests and educational goals.From these experts, it can be concluded that the work spirit of teachers is a profound pleasure to work being done to achieve better performance, although spirit of is not necessarily caused by working conditions.

Alex S Nitisemito (2004: 175) said that factors to measure work spirit are: (1) attendance showed the absence of teachers in their duties (2) cooperation in the form of collective action person against another person (3) job satisfaction as an emotional state pleasant or unpleasant, (4) discipline as an attitude and behavior in accordance with the regulations in written form.

\section{Personality.}

Atkinson (1993), Feist\&Feist (2002) says that personality is a pattern of behavior, character, characteristics and ways of thinking typical and permanent determining a person's adjustment to the environment.

Chaplin (2001: 131), Jung (in Zulkarnain \& Ginting, 2003) say that the personality of extroversion is a tendency to steer personality more out than inside oneself. A teacher who has the extrovert personality traits are social, more to do than contemplate (meditate, think), and the motifs are conditioned by external events.In connection with the above definition, the Atkinson (1983) and Stephen P. Robbins (2006: 126), suggests that personality is a dynamic organization in an individual who has a unique psiklogis system that can adapt to its environment.

\section{Emotional Intelligence.}

According to Goleman (2004: 1), Mu'tadin (2002: 1) emotional intelligence is coordinating the mood is the essence of good social relations. If a person is good at adjusting to the mood of another individual or empathize then that person will be more adaptable in social interaction as well as the environment.

Furthermore, Goleman (1977: 403-405) says some of the benefits of emotional intelligence, ie: (1) emotional self-awareness; ie improvement in recognizing and feeling his own emotions, better able to understand the causes of feelings that arise, and recognize the difference feeling to the action; (2) Managing emotions; ie a higher tolerance for frustration and anger management; (3) Utilizing emotions productively; ie more responsible, more self-controlled, and more able to focus on the tasks that must be done; (4) Empathy or the ability to read the emotions of others; ie more able to accept the viewpoint of laindan better in mendengrakan others; (5) Establishing relationships; ie improving the ability to analyze and understand relationships with others.

From the description and explanation of the above can be said that emotional intelligence is the teachers' attitude and honest behavior indicated a teacher in carrying out their duties. Attitudes and behavior is characterized by recognizing the emotions themselves, recognizing emotions in others (empathy), to motivate oneself, and relationships, as well as a good attitude towards his job.

\section{Job Satisfaction.}

According to Riggio (1996: 219), Handoko (1992: 193), As'ad (1995: 104), Tulus (2006: 189) job satisfaction consists of a feeling and attitudes about the person's work covers all aspects of a particular job, good and bad, positive and negative, contributed to the development of a feeling of satisfaction.

Meanwhile, according to Handoko (1992: 193) job satisfaction is an emotional state that is pleasant or unpleasant for teachers in view of his work. Meanwhile, according to M. L. Bhim quoted from As'ad (1995: 104) job satisfaction is the general attitude the result of some special attitude towards factors of work, adjustment and individual relationships outside of work. The term job satisfaction refers to an individual's general attitude toward his work. Someone with high job satisfaction showed a positive attitude towards work and vice versa if the person is not satisfied with his work showed a negative attitude towards the job.

Tulus (2006: 189), Wilson (1999: 112) job satisfaction is an positive attitude labor to the job, which comes under the assessment of the employment situation. The assessment can be performed on one work, the assessment is as respect in achieving one of the important values in the work. Teachers are satisfied preferred work situation than not like it.

The purpose of the job satisfaction of teachers in an educational institution does not come by itself, but must be created by the leadership of the school. Creation of job satisfaction of teachers aimed at improving the morale of teachers and improved school work. According Hasibuan (1995: 222) Job satisfaction should be created as well as possible in order to morale, dedication, love, work discipline, and work performance 
increased.Greenberg and Baron (2003: 159) gives advice to prevent dissatisfaction and increase the satisfaction of the following ways: (1) create a fun job, (2) those paid by honest, (3) bring together people with jobs that match their interests, (4) avoid boredom and repetitive work.

From the above opinion can be seen that the purpose of the education agency creates job satisfaction of teachers is to improve morale, dedication, love of work, and work discipline. Because, an increase in employment of teachers will have positive impacts on the performance of teachers. Teachers who has good achievementis a qualityteacher who works well, it works great quantity, reliable, friendly, initiative, diligently, always present in the work, and has the potential to move forward (Bittle and Newstrom, 1994: 218). Schools that have faculty who excel in turn can create a competitive edge in the world of school and educational institutions to produce students with the example and excel in various sciences.

\section{Data of Extraversion Personality Variable}

\section{RESEARCH RESULTS}

Based on indicators statement extroversion teacher personality variables $\left(\mathrm{X}_{1}\right)$ obtained the lowest score is 58 and the highest is 136 . The average 90.74 standard deviation 17.74, median 87.00, and 89.00 mode. Data show that the distribution of data tends to be normally distributed.

The results of data analysis shows the distribution of scores ekstrovers Personality $\left(\mathrm{X}_{1}\right)$ as many as 62 people $(45.58 \%)$ were below average class interval and as many as 23 people $(16.91 \%)$ were at an average class interval and as many as 51 people $(37.50 \%)$ above average or excellent category. Based on the above data, the extrovert personality of teachers generally are above average.

2. Data of Emotional IntelligenceVariable

Based on indicators variable of emotional intelligence $\left(\mathrm{X}_{2}\right)$ obtained the lowest score is 56 and the highest is 117 . The average 89.79 standard deviation $15.491,89.00$ median, and mode 89 . In accordance with the results of the calculation of basic statistics that have performed, shows the distribution of emotional intelligence scores $\left(\mathrm{X}_{2}\right)$ as many as 19 people (13.97\%) were below average class interval and as many as 21 people $(15.44 \%)$ were at an average class interval and as many as 96 people $(70,58 \%)$ above the category average or better. Based on the above data, the generally Emotional intelligence is above average or excellent category.

\section{Data of Job Satisfaction Variable}

Based on indicators statement Job satisfaction variable $\left(\mathrm{X}_{3}\right)$ obtained the lowest score was 52 and the highest is 116 . The average 78.82, 14.334 standard deviation, median 76.00, and 73. The mode of distribution of these data showed that the distribution of data tend to normal distribution. The results of data analysis showed job satisfaction score distribution $\left(\mathrm{X}_{3}\right)$ as many as 22 people $(16.17 \%)$ were below average class interval and as many as 36 people $(26.47 \%)$ were at an average class interval and as many as 78 people ( $57.35 \%)$ above the average. Based on the above data, the job satisfaction $\left(\mathrm{X}_{3}\right)$ generally is above average or excellent category.

\section{Data of Work Spirit Variable}

Based on indicators statement work spirit variable $\left(\mathrm{X}_{4}\right)$ obtained the lowest score was 61 and the highest is 119 . The average $88.45,14.220$ standard deviation, median 86.50 , and 87.00 mode. The distribution of these data shows that the distribution of the data tend to have normal distribution.

The test results have shown that the distribution of scores work spirit $\left(\mathrm{X}_{4}\right)$ as many as 46 people $(33.82 \%)$ were below average class interval and as many as 22 people $(16.17 \%)$ were at an average class interval and as much $56(41.17 \%)$ above average or excellent category. Based on the above data, the work spirit $\left(\mathrm{X}_{4}\right)$ generally is above average or excellent category.After testing requirements analysis, the next step is testing the hypothesis of the study, but first the path analysis was done to determine the coefficient of path. Based on the results of tests performed by using path analysis shows the path coefficient value and significance. Based on the results of tests carried out, the complete overall path coefficients can be explained as follows:

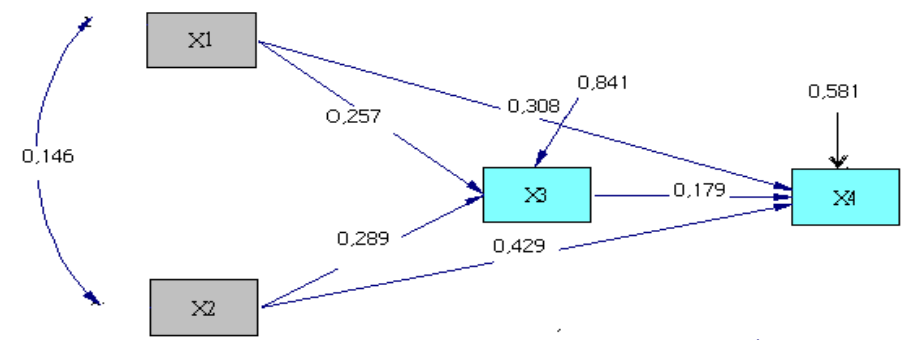

Figure 1 :The Results of the Research Based on Path Analysis 
Based on the figure above all path coefficients are significant. Results summary of direct and indirect effect can be seen in the table below.

Tabel1 :Summary Correlation, Direct Effect, Indirect Effect and the Simultan effect

\begin{tabular}{|c|c|c|c|c|c|}
\hline \multirow{2}{*}{ Variables } & \multirow{2}{*}{$\begin{array}{c}\text { Path } \\
\text { Coefficien } \\
\text { t }\end{array}$} & Direct & $\begin{array}{c}|c| \\
\text { Indirect effect } \\
\text { through } \mathbf{X}_{3}\end{array}$ & Total & $\begin{array}{c}\text { Simult } \\
\text { an } \\
\text { Effect }\end{array}$ \\
\cline { 3 - 4 } & 0.308 & 0.308 & - & 0.308 & - \\
\hline $\mathrm{X}_{1}$ & 0.429 & 0.429 & - & 0.429 & - \\
\hline $\mathrm{X}_{2}$ & 0.179 & 0.179 & - & 0.179 & - \\
\hline $\mathrm{X}_{3}$ & 0.257 & - & 0.257 & 0.257 & - \\
\hline $\mathrm{X}_{1} \mathrm{X}_{3}$ & 0.289 & - & 0.289 & 0.289 & - \\
\hline $\mathrm{X}_{2} \mathrm{X}_{3}$ & 0.841 & $0.841^{2}=70.7$ & - & - & - \\
\hline${ }_{\varepsilon}$ & 0.581 & $0.581^{2}=33.75$ & - & - & - \\
\hline${ }_{\varepsilon}^{2}$ & - & - & - & - & 0.432 \\
\hline $\begin{array}{c}\mathrm{X}_{1} \mathrm{X}_{2} \text { dan } \\
\mathrm{X}_{3} \text { to } \mathrm{X}_{4}\end{array}$ & & - & & & \\
\hline
\end{tabular}

\section{DISCUSSION}

Results of testing the first hypothesis suggests that that the results of the analysis of path known to pyX1 has a path coefficient of 0308 , the value of the path coefficient also shows the influence of variables $X_{1}$ to $\mathrm{X}_{4}$ is equal to $30.8 \%$, it can be concluded that the effect of $\mathrm{X}_{1}$ to $\mathrm{X}_{4}$ significant because $\mathrm{t}$ observed $>\mathrm{t}$ table and $\mathrm{P}<0.05$. Based on the above hypothesis is empirically been proven that the personality of extroversion, held by teachers, affect the increased work spirit.

Morale is the mental attitude and feelings of individuals and groups to their work environment in which mental attitude and feelings of the individual reflected their interests, passion, and drive to work being done. While the attitude is reflected in the relations of cooperation between teachers in educational institutions. Extroversion personality is a personality that describe someone who is outgoing, carefree and confident, and tend to exhibit characteristics of a very quiet, relaxed, do not have excessive ambition and gregarious, assertive and able bersoalisasi. From the above it can be said that teachers have the personality characteristics of extrovert will impact on work spirit in carrying out its duties and functions as teachers and educators in order to improve the quality of education of their students as expected and the standards outlined by the Ministry of National Education.

The second hypothesis testing results show that the analytical results $\rho y \mathrm{X} 2$ path has path coefficient of 0.429 , the coefficient of this line also shows the effect of variable $\mathrm{X}_{2}$ to $\mathrm{X}_{4}$ that is equal to $42.9 \%$. Furthermore, to test whether the effect of variable $\mathrm{X}_{2}$ to $\mathrm{X}_{4}$ is significant or not, the test results from the test two directions known tcount amounted to 6,172 and the value of $P=0.000$ at significance level of $5 \%$ with $\mathrm{db}=136$, t table is 1,645 , it can be concluded that $\mathrm{X}_{2}$ to $\mathrm{X}_{4}$ significant effect for $\mathrm{t}$ observed $>\mathrm{t}$ table and $\mathrm{P}<0.05$. Based on the above hypothesis is empirically been proven that emotional intelligence (emotional intellligence) is the ability to recognize our own feelings and the ability to manage emotions well in ourselves and in relationships with others. Thus, emotional intelligence includes self-control, passion and perseverance and the ability to motivate yourself, and able to withstand the frustration and stress that self-control and moral control. Morale is a profound pleasure to work being done to achieve better performance, although morale is not necessarily caused by working conditions, but by the desire and willingness to do his job well, disciplined to achieve maximum performance.

Therefore, emotional intelligence has a significant positive relationship to the work spirit of of teachers, as well as the effect on the work spirit of of teachers. From the foregoing it can be argued that the emotional intelligence of teachers has to do with the morale of teachers, in other words whether or not the emotional intelligence affect the morale of teachers. Therefore, it is suspected that there is influence of emotional intelligence on the work spirit of teachers.

The third hypothesis testing shows the path coefficient analysis results of 0179 , the value of the path coefficient also shows the influence of $\mathrm{X}_{3}$ to $\mathrm{X}_{4}$ is equal to $17.9 \%$. Based on test results to test two directions known value of $t$ observed equal to 2.479 and the value of $\mathrm{P}=0.000$ at significance level of $5 \%$ with $\mathrm{db}=136, \mathrm{t}$ table is 1.645 , it can be concluded that a significant effect of $\mathrm{X}_{3}$ to $\mathrm{X}_{4}$. Therefore, job satisfaction is a positive attitude of teachers as teachers includes feelings and attitudes towards work through the assessment of one job as a sense of respect in achieving one of the essential values of the work itself. 
Morale is a profound pleasure to work being done even though work spirit of is not necessarily caused by the working environment. If the school is able to improve the work spirit of the teachers and the work will be expedited and ultimately educational objectives will be achieved in accordance with the vision and mission of the school. The decline in spirit of would automatically affect the performance of teachers, where indications of a decrease in work spirit of can be seen from the fall or the low labor productivity, high absenteeism, anxiety everywhere, demands that often occur, and a strike. Thus, the increase in teachers' work spirit can be understood that the issue of understanding about the work spirit of is essential in carrying out an educational activity, both public and private educational institutions in order to achieve educational goals.

The Improvementof work spirit of teachers is influenced by several factors such as the level of welfare sufficient to live comfortably in terms of both financial and non financial, as well as job satisfaction level is high in carrying out its duties and functions optimally in teaching and educating students in accordance with the standards of competence outlined. Therefore it is presumed that there is no direct impact on job satisfaction on the work spirit of teachers. The fourth hypothesis testing of the analytical path results known to have had a path coefficient of 0.257 , the value of the path coefficient also shows the influence of variables $X_{1}$ to $X_{3}=25.7 \%$. Furthermore, to test whether the effect of variable $X_{1}$ to $X_{3}$ is significant or not, the test results from the test two directions known $\mathrm{t}$ observed $=3.217$ and the value of $\mathrm{P}=0.000$ at the significance level of $5 \%$ with $\mathrm{db}=136$, $\mathrm{t}$ table is 1.645 , it can be concluded that $\mathrm{X}_{1}$ to $\mathrm{X}_{3}$ significant influence because. This test proves that the personality of the teacher who extroversion that describes someone who is outgoing, carefree and confident, and tend to exhibit characteristics of a very quiet, relaxing, no ambitions of excessive and gregarious, assertive and are able to socialize will have an impact on increasing work satisfaction. Therefore, there is an influence can be presumed extroversion personality on job satisfaction of teachers.

Testing of fifth hypothesis shows the path analysis for 0.289 , the value of the path coefficient also shows the influence of $\mathrm{X}_{2}$ to $\mathrm{X}_{3}$ that is equal to $28.9 \%$. Based on these findings proved that emotional intelligence includes self-control, passion and perseverance and the ability to motivate oneself, and able to withstand the frustration and stress can increase the job satisfaction of teachers. Therefore, there is a significant relationship between the level of emotional intelligence and job satisfaction.

While the results of the sixth hypothesis testing based on the analysis of multiple regresion known coefficient of determination for 0.432 , the value of determination coefficient indicates the magnitude of the total effect of the variables $X_{1}, X_{2}$, and $X_{3}$ to $X_{4}=43.2 \%$. Furthermore, to test whether the total effect of variables $\mathrm{X}_{1}, \mathrm{X}_{2}$, and $\mathrm{X}_{3}$ to $\mathrm{X}_{4}$ is significant or not, comparing with $\mathrm{F}$ observed with $\mathrm{F}$ table. If $\mathrm{F}$ observed $>\mathrm{F}$ table then the influence is significant. From the results of analysis $\mathrm{F}$ observed $=33,441$ and $\mathrm{F}$ table $=4.20$ at a significance level of $5 \%$. Since $F$ observed $>F$ table the influence of $\mathrm{X}_{1}, \mathrm{X}_{2}$, and $\mathrm{X}_{3}$ to $\mathrm{X}_{4}$ is significant, then $\mathrm{H}_{0}$ is rejected while Ha accepted.

Based on the above findings seen empirically proven that the teacher's personality shown extroversion, emotional intelligence and job satisfaction of teachers and the important factor is decisive in terms of improving teacher spirit. Teachers are important components that relate directly to teaching and learning in the classroom. Failure teachers in implementing the teaching and learning activities in the classroom, will affect the process of achieving the goals. As a teacher should have a personality that describes someone who is outgoing, carefree and confident, and tend to exhibit characteristics of a very quiet, relaxed, do not have excessive ambition and gregarious, assertive and are able to socialize. Intelligent can be defined as the ability to recognize, manage and express themselves appropriately, including to motivate oneself, familiar with other people's emotions, and relationships with others. Clearly if an individual has a high emotional intelligence will be able to live happy and successful as confident and able to control emotions or have good mental health. Job satisfaction is a person's general attitude towards work which shows the difference between the number of awards received by workers with the amount they believe they should receive. Therefore, job satisfaction is a positive attitude of the workforce includes feelings and attitudes towards work through the assessment of one job as a sense of respect in achieving one of the essential values of the work itself

Morale is a profound pleasure to work being done even though morale is not necessarily caused by the working environment. If the school is able to improve the morale of the teachers and the work will be expedited and ultimately educational goals that have been outlined will be achieved, as well as students who attained the better its quality. The decline in morale would automatically affect the performance of teachers, where indications of a decrease in morale can be seen from the fall or the low labor productivity, high rate of absenteeism, labor turnover is high, anxiety everywhere, demands that often occur, and the occurrence of strikes work. Thus, an increase morale of teachers from an educational institution in this school is very complex, so it can be understood that the issue of understanding the spirit of the work is a matter that is essential in carrying out the educational activities of a school, both public schools and private sectors in an effort to achieve educational goals or the vision and mission of the school tersebut.Peningkatan teacher morale is influenced by several factors such as personality types of teachers extroversion outgoing, carefree and confident, and tend to exhibit characteristics of a very quiet, relaxed, emotional intelligence good teachers in recognizing himself and 
others around them, as well as a high level of job satisfaction in carrying out its duties and functions optimally in teaching and educating students in accordance with the competency standards set by the Ministry of National Education. Therefore alleged no direct impact on the personality of extroversion, emotional intelligence and job satisfaction on the work spirit of teachers.

study are:

This study has been designed carefully and thoroughly, but do not close the possibility of flaws in this

1. Research on work spirit seen only three variables, namely the personality of extroversion, emotional intelligence and job satisfaction so that depicted only these three variables impact on morale. So, we need a more comprehensive study with other variables.

2. Positivism research approach which uses quantitative methods have difficulty in measuring the things that are qualitative, for example, of the entire working Discipline has not been approached from the other side, such as the factor of leadership, policy and decision making factors, as well as other factors.

3. The possibility of respondents are less serious in completing research or complete a questionnaire given to the answers given less describe the actual results.

\section{CONCLUSION}

Based on the analysis described earlier can be summarized as follows:

1. Extraversion personality relates and have a significant effect on work spirit by $30.8 \%$.

2. Emotional Intelligence relates and have a significant effect on work spirit by $42.9 \%$.

3. Job satisfaction relates and have a significant effect on work spirit by $17.9 \%$.

4. Extraversion personality relates and have a significant effect on job satisfaction by $25.7 \%$.

5. Emotional intelligence relates and have a significant effect on job satisfaction by $28.9 \%$.

6. While the total effect of extroversion personality variables, emotional intelligence and job satisfaction on work spirit by $43.2 \%$, while the remaining $56.8 \%$ came from other variables.

\section{SUGGESTION}

The suggestions were submitted in connection with the findings of this study are as follows

1. Head of the Ministry of Religious Affairs of Medan and staffs are related, especially in terms of increased work spirit are advised to give special attention in these regards: 1) to provide guidance on the ability of school principals in carrying out its duties and responsibilities, 2) provide rewards for teachers who excel in performing their duties , 3) open opportunities for principals to continue their education at a higher level.

2. Improving the ability of school leadership should continue to be developed through training and effective upgrading so it will be a positive motivating factor for increasing work spirit.

3. Another researcher, suggested to follow up this study with different variables that also contribute to work spirit.

\section{REFERENCES}

[1] Agustian, Ary Ginandjar, 2001, Rahasia Sukses Membangun Kecerdasan Emosional dan Spritual: ESQ Berdasarkan 6 Rukun Imandan 5 Rukun Islam, Jakarta: Arga.

[2] Anoraga, Pandji, 2002, Psikologi Kerja, Jakarta: Rineka Cipta.

[3] Arikunto, Suharsimi, 2001, Prosedur Penelitian Suatu Pendekatan Praktek, Yogyakarta: Rineka Cipta.

[4] As'ad, 2002, Manajemen Personalia, Yogyakarta : Andi.

[5] Budianto, 2008, Hubungan Kecerdasan Emosional Terhadap Kepuasan Kerja Guru,Makalah, Medan : Universitas Sumatera Utara (USU).

[6] Edward A., 2009, Pengaruh Kesejahteraan Terhadap Semangat Kerja Guru padaSMK Quickly Medan, Makalah, Medan: Universitas Sumatera Utara (USU).

[7] Fauzi, Harry D., 2004, Pengaruh Kesejahteraan Terhadap Kinerja Guru pada SMU Negeri 3 Medan, Makalah, Medan: Universitas Muhammadiyah Sumatera Utara (UMSU).

[8] Gibson, 2000, Manajemen Sumber Daya Manusia, Yogyakarta : Andi.

[9] Greenberg dan baron, 2003, Cara Mengukur Tingkat Kepuasan Kerja Karyawan dalam Perusahaan,Jakarta: Salemba Empat.

[10] Hadari Nawari, 2003, Metode Penelitian Bidang Sosial, Yogyakarta: UGM Press.

[11] Handoko, T. Hani, 2001, Manajemen Personalia dan Sumber Daya Manusia, Yogyakarta: BPFE-UGM.

[12] Harmoko, Agung R., 2005, Manfaat Kecerdasan Emosional (EQ) dalam Membantu Aktivitas Kerja Pegawai, Jakarta: Rineka Cipta.

[13] Hasibuan, Malayu S.P, 2007, Manajemen Sumber Daya Manusia, Jakarta: Bumi Aksara.

[14] Heidjrachman Ranupandojo dan Suad Husnan, 2002, Manajemen Personalia, Yogyakarta: BPFE-UGM.

[15] Hidayat dan Mashum, 2005, Cara Mengelola EQ yang Efektif, Jakart: Haifa. 
[16] Imam, Eko, 2004, Kecerdasan Emosional di Tempat Kerja, Jakarta: Rineka Cipta.

[17] Ismail, 2009, Pengaruh Kesejahteraan Terhadap Semangat Kerja Karyawan pada PT. Eka Pratama Jaya Medan,Makalah, Medan: Universitas Dharmawangsa.

[18] Iswahyuni, 2008, Hubungan Kecerdasan Emosional dengan Semangat Kerja Guru pada SMP Swasta Al Azhar Medan, Makalah, Medan: Universitas Al Azhar.

[19] Karyana, Aang, 2002, Pengaruh Penempatan dan Kepuasan Kerja Terhadap Produktivitas Kerja Guru pada SMU Negeri 2 Medan, Medan: Universitas Sumatera Utara (USU)

[20] Kreitner dan Kinicki, 2005, Kepuasan Kerja dan Pengaruhnya Terhadap Produktivitas Kerja Karyawan, Yogyakarta: Ghalia Indonesia.

[21] Manullang, M, 1999, Manajemen Personalia I,Medan: FE-UMI.

[22] Mudjahid, Sodik, 2005, Kecerdasan Emosinal Menstabilkan Diri Individu, Jakarta: SalembaEmpat.

[23] Nitisemito, Alex S., 2004, Manajemen Personalia, Yogyakarta: Ghalia Indonesia.

[24] Nuzullia, Lia, 2009, Hubungan Pemberian Kesejahteraan dengan Kepuasan Kerja Pegawai pada PT. Pertamina UPMS-1 Medan,Makalah, Medan: Universitas Sumatera Utara (USU).

[25] Pedhazur, 1982, MetodePenelitian di BidangPendidikan, Jakarta: Prenticehall.

[26] Ranupandjojo dan Husnan, 2002, Manajemen Sumber Daya Manusia,Yogyakarta: BPFE-UGM.

[27] RiduwandanKuncoro, 2008, Cara Menggunakan dan Memaknai Analisis Jalur (Path Analysis),Jakarta:Alfabeta.

[28] Robbins, 2006, Manajemen Sumber Daya Manusia,Jakarta: Erlangga.

[29] Sahertian, 2000, Profesionalisme Guru,Bandung: Remaja Rosdakarya.

[30] SaifuddinAzwar, 2002, Manajemen Sumber Daya Manusia, Jakarta: Gramedia Pustaka Utama.

[31] Schumacer \& Lomax, 1996, Metode Penelitian Bisnis, Jakarta: Rineka Cipta.

[32] Siagian, Sondang P, 2006, Manajemen Sumber Daya Manusia, Jakarta: Bumi Aksara.

[33] Silalahi, Maratua S., 2008, Pengaruh Tingkat Kesejahteraan Terhadap Kepuasan Kerja Guru pada SMP Negeri 1 Labuhan Deli, Makalah, Medan: Universitas Methodist.

[34] Sopana, Pandu, 2008, Pengaruh Kecerdasan Emosional Terhadap Kinerja pada SMK Swasta Sinar Husni, Makalah, Makalah, Medan: UniversitasMuhammadiyah Sumatera Utara (UMSU).

[35] Steven dan Howard, 2002, Ledakan EQ,Jakarta: Kaifa.

[36] Sudjana, 2001, PenilaianHasil Proses BelajarMengajar, Bandung: RemajaRosdakarya.

[37] Sudjana, Nana, 2001, MetodaStatistika, Bandung :Tarsito.

[38] Sugiyono, 2009, MetodePenelitian, Bandung :Alfabeta.

[39] Suwandi, 2009, Pengaruh Kecerdasan Emosional Terhadap Semangat Kerja Guru pada SMU Swasta Sutomo Medan, Makalah, Medan : Universitas HKBP Nommensen.

[40] Tohardi, Ahmad, 2002, Pemahaman Praktis Manajemen Sumber Daya Manusia, Bandung: Mandar Maju.

[41] Tulus, Mohd. Agus, 2006, Manajemen Sumber Daya Manusia, Jakarta: Gramedia Pustaka Utama.

[42] Wulandari, 2007, Pengaruh Kecerdasan Emosional Terhadap Kepuasan Kerja Guru pada SMU Swasta Sultan Iskandar Muda Medan, Makalah, Medan: Univeristas Muhammadiyah Sumatera Utara (UMSU). 